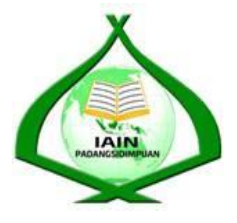

ENGLISH EDUCATION

English Journal for Teaching and Learning

Vol. 07 No. 01 June 2019 page 127 - 139

http://jurnal.iain-padangsidimpuan.ac.id/index.php/EEJ

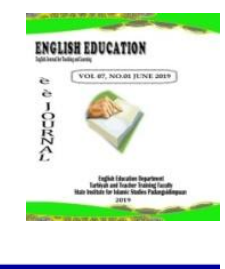

\title{
Improving Students' Reading Comprehension through Guessing Strategy
}

\section{Dewi Fatimah Sitompul, Eka Sustri Harida, and Sojuangon Rambe* Institut Agama Islam Negeri (IAIN) Padangsidimpuan \\ Email : ekasustri@iain.padangsidimpuan.ac.id,sojuangonr@gmail.com}

Abstract The purposes of this research were: to describe the students' reading comprehension through guessing strategy and to identify the factors which influenced students' reading comprehension through guessing strategy at Grade XI MAS Darul Istiqomah Hutapadang - Pijorkoling. This research used classroom action research consisted of two cycles. Moreover, the participants of this research were the class of XI (19 students) and there was collaboration with an English teacher. Meanwhile, the data was derived from reading comprehension tests, observation, and interview. Students' score in cycle 1 was $62.24(4 \%)$ and students' score in cycle 2 was 78.68 (79\%). Based on the research result in cycle 1 and cycle 2, it showed the improvement of students' mean score and students' percentage. So, students' improvement in reading comprehension through guessing strategy was good category (high).

Key Words: reading comprehension; guessing strategy; reading strategies; action research; loud reading

Abstrak Penelitian ini bertujuan untuk menggambarkan kemampuan membaca pemahaman siswa melalui guessing strategy dan untuk mengidentifikasi faktor-faktor yang mempengaruhi kemampuan membaca pemahaman siswa melalui guessing strategy pada kelas XI MAS Darul Istiqomah Hutapadang - Pijorkoling. Penelitian ini menggunakan penelitian tindakan kelas dengan dua siklus. Partisipan dalam penelitian ini adalah 19 siswa kelas XI dan berkolaborasi dengan guru bidang studi. Data dikumpulkan melalui reading comprehension test, observasi, dan wawancara. Skor siswa pada siklus 1 adalah 62.24 (4\%) dan pada siklus 278.68 (79\%). Hasil penelitian dari siklus 1 dan 2 menunjukkan peningkatan persentasi rata-rata skor. Dengan demikian, peningkatan kemampuan membaca pemahaman siswa melalui guessing strategy adalah pada kategori baik (tinggi).

Kata Kunci: reading comprehension; guessing strategy; reading strategies; action research; loud reading

E-ISSN : 2579-4043

P-ISSN: $2338-8781$

" Corresponding Author : ekasustri@iain.padangsidimpuan.ac.id 


\section{INTRODUCTION}

The one way that we can do to get information is reading. Reading is presented by written form through electronic, paper, book, article, script and others. In other word, it is a tool to give the explanation or description about something. We can read about the all knowledge we want to know. We can read whatever, whenever, wherever, and however we pleases. We can go at our own pace and can slow down or speed up, take intermission, reread, or pause and think at our pleasure where those are as our activities in reading. Moreover, reading serves many purposes such as finding the information, instruction to do something, concluding the information, making the writing, article, paper or others.

Reading is important to get the information in all aspect. Likewise, it names as the one of information source that Allah SWT, taught to the human for getting the knowledge. In other words, the science has to search as life guidance for be loyal. Reading also helps the students to answer the question that refers to the subject matter they are studying. They search the answer in reading the information about the question they have. Reading gives them much information that they need besides the other way such as interview someone, look for in the internet, in document but it doesn't release from the reading. To sum up, to answer the question that appears in learning process can be exceeded by the reading the other information that refers to the subject matter.

However, Students' reading comprehension achievement was low. We could see the students' English values in their school report book. Their reading average values of grade X: 60 (12\%), grade XI: 65 (7\%) and grade XII: 60 (22\%). ${ }^{1}$ Based on that values we could conclude that their English ability was low includes reading skill. Besides, the researcher interviewed the English teacher in this school; she said that the students had low values especially in reading comprehension which it was supported by their values in reading test. Besides, the students got difficulty to get the important information. Getting the important information is often appearing in the examinations especially in reading comprehension where it must

${ }^{1}$ List book of students' value at MAS Darul Istiqomah Hutapadang - Pijorkoling, private Document, (MAS Darul Istiqomah Hutapadang - Pijorkoling: November 25 th 2014 at 10:30 am). 
be done quickly. In this case, the students considered it took long time to do it quickly. So, it made them difficult to pass the examination and answered another questions.

The last aspect was the students got difficult to comprehend English text. They just read all the word in the text and looked for the meaning of the word in dictionary. After all the word had a meaning based on the dictionary meaning, they translated it by lexicon of the word without necessary the context meaning or real meaning in the text. So, according to their translation, it made them difficult to comprehend the text or it could be said as ambiguity meaning.

These problems above need to solve to overcome the students' problem in reading comprehension. $\mathrm{H}$. Douglas Brown argued that there were some strategies were related to bottom-up procedures and other enhances the top-down processes those could be applied as strategies for reading comprehension, one of them is guessing strategy as the strategy to improve the students' reading comprehension..$^{2}$ It is easy to apply for reading comprehension according to the researcher. The characteristics of the guessing strategy where it was compared with the other strategies focus on reading comprehension will be explained by following sentences.

Based on the identification above, the researcher focused the problems in improving students' reading comprehension achievement that would be solved by doing guessing strategy. This research was conducted by classroom action research (CAR) by title Improving Students' Reading Comprehension Through Guessing Strategy At Grade Xi Mas Darul Istiqomah Hutapadang - Pijorkoling.

Reading is an activity that done by someone to get information about something. The linguistics state about reading in many ways, such as Albert J. Harris says that reading is the meaningful interpretation of written or printed verbal symbols. It can apply also to the interpretation of mathematical, musical notation, codes, and other symbolic systems. ${ }^{3}$ At the same words, David Nunan argues that reading is a fluent process of readers combining information from a

${ }^{2}$ H. Douglas Brown, Language Assessment; Principles and Classroom Practices, (USA: Longman, 2004). p. 291-296.

3 Albert J. Harris, How to Increase Reading Ability; A Guide to Developmentaland Remedial Methods, Fifth Edition, (New York: David Mckay Company, Inc, 1969), p. 3. 
text and their own background knowledge to build meaning. ${ }^{4}$ To sum up, reading is a fluent process of readers combining information from a text and their own background knowledge that involve the meaning is self-evident or must always be a meaning process by written or printed verbal symbols. It helps the reader to get the information either to get the new or increasing the information.

There are many types of reading, as the following illustrates about it:

\section{1) Silent Reading}

Silent reading is the way of reading by silent or without oral in reading which it is using visual memory and condition of not speaking to relay pay attention in understanding of a text. Situation or condition of the reader physically or mentally will influence the quality of readers' comprehension in reading silent.

\section{2) Loud Reading}

Loud reading is the activity of reading that using voice or pronounce it loudly until the reader and the people at they around listen what they are reading where it is relatively uncommon in modern language process. It helps them increase their ability in pronunciation or speech.

Albert J. Harris divides the three types of reading as following sentences;

1) Developmental reading

2) Functional reading

3) Recreational reading

A teacher of reading wants his/her students to be able to read, to use reading effectively as a learning tool, and to enjoy and appreciate reading. The three types of reading purposes cannot and should not be kept entirely separate. In a developmental lesson students must be read material which is either recreational or functional in character.

Comprehension is the process by which a person understanding the meaning of written or spoken language clearly. ${ }^{5}$ The process in understanding meaning of written or spoken language has the rules or steps to bring the reader in comprehending. The rules can know the meaning of word, having the background knowledge, knowing the implied or implicit meaning, analyzing the purpose of

${ }^{4}$ David Nunan, Practical English Language Teaching, (New York: Mc. Grow Hill, 2003), p. 68.

5 Richard A. Renandya. Language Teaching methodology, (Cambridge: Cambridge University, 2000), p. 24. 
the author, and the other cases. Besides, David Nunan says that monitoring comprehension is essential to successful reading. ${ }^{6}$ The main goal of reading is comprehension absolutely, either for details or not. The reader who has the background knowledge about something, it must comprehend firstly. In other words, it can be said that comprehend something to comprehend another case. In summary, comprehension is the process in reading which the reader understanding the meaning of written form or printed material where it is the main purpose of reading. It has the ways or the rule that has to reader had to do it easily. Either the situation or condition of the reader in process understanding must be concerned.

Smith in Wayne Otto at, al book divides the level of reading comprehension into four categories, they are:

1) Level 1 - Literal Comprehension - getting the direct meaning that has been explicitly stated

2) Level 2 - Interpretation - identifying ideas not explicitly stated

3) Level 3 - Critical Reading - evaluating what is read

4) Level 4 - Creative Reading - applying ideas read to new situations. ${ }^{7}$

There are some factors influence the comprehension, they are;

1) The Rate of Reading

2) The objective of Reading

3) The quality of Reading material

4) The position order of reading material

5) The circumference in reading 8

The factors above, shows us either quantity or quality of the readers' comprehension to reading material are the important one in reading. By taking note of the fifth factors can give us the improving in comprehension graduate, it may impossible to improve it instantly.

At the same case, Albert J. Harris ${ }^{9}$ argues the inability the reader to comprehend well is caused the factors bellow, they are;

${ }^{6}$ David Nunan, Practical English Language Teaching, (New York: Mc. Grow Hill, 2003), p. 75.

7 Wayne Otto, How to Teach Reading, (U.S.A: Addison-Wesley Publishing Company, 1979), p. 153.

${ }^{8}$ Gordon Wainwright, Speed Reading Better Recalling; Manfaatkan Teknik-teknik Teruji untuk Membaca Lebih Cepat dan Mengingat Secara Maksimal, (Jakarta: PT. Gramedia Pustaka Utama, 2007), p. 44.

9 Albert J. Harris, How to Increase Reading Ability; A Guide to Developmentaland Remedial Methods, Fifth Edition, (New York: David Mckay Company, Inc, 1969), p. 445-447. 
1) Intellectual limitation

2) Word recognition difficulties

3) Poor comprehension resulting from inappropriate rate

4) Poor concentration

5) Difficulties in specific types of comprehension

Much attention to these factors gives us the improving completely in comprehension. In contrast, these factors are the main causes which make the reader inability to comprehend well. In the analysis of comprehension disability, someone has to analyze the reasons for detective understanding and the remedial procedures to do it must be selected accordingly.

Reading comprehension is an ability to understand what the readers read that involves the exploitation of the other skills or ability where there is reflection of the communicative interactions among the intentions of the reader and the context or situation of interaction.

Next, there are indicators in reading comprehension that want to be developed in expressing the meaning of the words, content of message, and infer implied meaning. The indicators for reading comprehension are the following sentences:

1) Topic sentence

Topic sentence is a sentence that refers to the main idea or message in the paragraph.

2) Important information

Important information is facts or details about the text which it has great effect or value as specific information and a piece of story that refers to accident, behaviour and character of the actors, and the actors of the text.

3) Content of the message

Content of the message is global information that refers to a core of the story and problem in the text.

4) Meaning of difficult word/ idiom/ phrases in context

Meaning of difficult word/ idiom/ phrases in context is a word or phrase that refers to lexical and contextual meaning, idiom and a pronoun that identifies a subject of the sentence.

5) Conclusion of the text 
Conclusion of the text is a sentence that refers to a summary, ending, moral or learning and problems' solving in the story.

In this research, the researcher uses reading text about, Eliza and Athena Tangkuban Perahu, The Legend of Toba Lake, and Lutung Kasarung. The essay test is 20 items for filling reading test. This test must be scored objectively and measured learning out come directly. The indicators for the reading comprehension is scored 1 each indicators. Because, there are 20 items, so the total score for all indicators are 100 .

Guessing is essential for listening and reading. It helps the learners let go of the belief that they have to recognize and understand every single word before they can comprehend the overall meaning. Learners can actually understand a lot of language through systematic guessing, without necessarily comprehending all the details.

Build guessing skills systematically by leading students step by step through different stages of guessing. Start with global comprehension. To stimulate guessing, the researcher ask the students some preview questions before they start reading, or interrupt a story in the middle to ask for guess about the beginning. The researcher asks the students which picture corresponds to what they are reading. Alternatively, the researcher gives students a sentence in the new language and asks them to complete it. The researcher also gives them feedback immediately or soon about the correctness or appropriateness of their answers. Then, the researcher and the students discuss the source of the guesses to make the students learn from each other and the researcher knows whether the students are using all possible sources of clues. ${ }^{10}$ There are two strategies that relate to guessing strategy which the researcher applies in this research, they are;

\section{a. Using linguistic clues}

Guessing the meaning of the words, content of meaning until in inferring implied meaning, it can apply this strategy. Suffixes, prefixes and word order are useful linguistic clues to gain the knowledge of the language targets, the learners' own language, or some other language. It can provide linguistic clues to the

10 Rebecca L. Oxford, Language Learning Strategies; What Every Teacher Should Know, (New York: Newbury House Publishers, 1990), p. 94. 
meaning of what is read. Knowledge of the student's own language provides still more clues for understanding material heard in the new language. In the other words, linguistic clues are the bedrock of many correct guesses about the meaning of written passages.

\section{b. Using other clues}

Some clues are related to language but go beyond and others come from a variety of other sources which are not related to language. It can be a form of address, such as titles or nicknames, help the readers guess the meaning of what they read. It can be indicated of status which it is the aids for understanding the rest of the passage.

Others, text structure such as introductions, summarize conclusions, titles, transitions and ways of dividing the text. It is possible to obtain many clues by noticing the author's structural used of words, phrases, numbers and letters that indicate importance or priority. Graphs, pictures, tables and appendices can help readers get an idea of the meaning.

The procedures which the researcher uses for conducting the guessing strategy are;

1) Using Linguistic Clues

a) Asks the students to find and analyze suffix and prefix and linguistic clues in the text.

b) Asks the students to find the part of linguistic clues in the text.

2) Using Other Clues

a) Asks the students to find the form of address such as titles or nicknames.

b) Asks the students to see the structure of the text such as the Introduction, conclusion, title, Transition, proper name, grape, pictures and table in the text.

c) Asks the students to use their general background knowledge such as about culture, politic, art, or literature. 


\section{METHODO}

This research conducted in MAS Darul Istiqomah Hutapadang - Pijorkoling. This school there was in a village where it was about 2 kilometres from the crossroad to get the mini transport, in the Abror/ Pulau Bauk Street km. 10 Hutapadang - Pijorkoling, Padangsidimpuan city. Classroom action research was the kind of research to apply this research. There are two cycles applied by using Kemmis Spiral. The participant of this research was the Grade XI of MAS Darul Istiqomah Hutapadang - Pijorkoling.

The data were collected through reading comprehension test, observation, and interview. Test is used to know the ability of students where it is sequence of question or practice that will be used for surveying the skill, intelligence, knowledge or trail that is owned by individual or group. The other instrument to get the data in this research was observation where it needed to get information about phenomenon that occurs in learning - teaching process, by doing observation and recording toward visible phenomenon systematically. There were some kinds of observation; they are behavior checklist, observation notes, reflective observation, analytical observation, and narrative observation. But in this research, the researcher used observation notes in application. Moreover, interview has done to ask the English teacher, students and the other information that interlocked with this research to get the supporting data.

In this research the, the technique for analyzing data used quantitative and qualitative data. Qualitative data is used to describe the situation during the teaching process. The process of data analysis involves making sense out of text. It involves preparing the data analysis conducting different analysis, moving deeper into understanding of the larger meaning of the data. The qualitative data is used to analyze from the observation sheet. And then, Quantitative analysis to analyze the score of students in every their worksheet by using reading comprehension test.

\section{RESULT AND DISCUSSION}

Students' achievement in reading comprehension by using Guessing strategy at grade XI MAS Darul Istiqomah Hutapadang - Pijorkoling was described in this 
research as one of the purpose. The researcher found the improvement of students' mean scores and percentage in reading comprehension by using Guessing strategy based on first cycle and second cycle.

Based on the related findings of this research in chapter II, the students' achievements were: the first, Nursalimah Nasution had done research in IAIN Padangsidimpuan about “Improving Students' Reading Narrative Text Comprehension through Story Mapping Technique at Grade VIII MTsN 2 Padangsidimpuan". She said that Story Mapping Technique improved students reading narrative comprehension. In cycle 1 was $70.33(43.33 \%)$ and in cycle 2 was $80.83(86.66 \%)$. So cycle 2 was bigger that cycle $1(86.66 \%>43.33 \%)$.

The second, Indah Permata Sari had done research by title "Improving Students' Reading Comprehension by Using PQ4R (Preview, Question, Read, Reflect, Recite, and Review) Strategy at Grade VIII SMP Negeri 5 Padangsidimpuan In academic year 2013/2014". She said that PQ4R improved students reading comprehension by using PQ4R. In this study, it had found that the improvement of students' achievement by using PQ4R Strategy. Cycle 1 was $68.12(37 \%)$ and Cycle 2 was $83.12(95 \%)$. So cycle 2 was bigger that cycle 1 (95\% > $37 \%)$.

In this study, researcher also had found that the improvement of students' achievement through the title "Improving Students' Reading Comprehension Through Guessing Strategy at grade XI MAS Darul Istiqomah Hutapadang Pijorkoling". It was 62.24 (4\%) in first cycle, and it was 78.68 (79\%) in second cycle. So, the cycle 2 was bigger than cycle $1(79 \%>4 \%)$. The table below would show the different of the result;

The explanation below would show the different of the result as; Nursalimah Nasution as the first researcher, entitle "Improving Students' Reading Narrative Text Comprehension through Story Mapping Technique at Grade VIII MTsN 2 Padangsidimpuan". The result of her research were in cycle 1 was 70.33 (43.33\%) and cycle 2 was 83.12 (86.66\%). The second researcher was Indah Permata Sari entitle “Improving Students' Reading Comprehension by Using PQ4R Strategy At Grade VIII SMP Negeri 5 Padangsidimpuan In academic year 2013/2014". The result of her research were in cycle 1 was 68.12 (37\%) and cycle 2 was 80.83 (95\%). 
The third researcher was Dewi Fatimah Sitompul (Researcher in this research) entitle "Improving students' reading comprehension through guessing strategy at grade XI MAS Darul Istiqomah Hutapadang - Pijorkoling". The result of her research were in cycle 1 was 62.24 (4\%) and cycle 2 was 78.68 (79\%).

In doing the research, the researcher found some threats in this research, they were:

The data in this research were objective which the descriptions of students' score were based on the test in essay test that had certain score for each question items. The tool that used in collecting the result of students' reading comprehension was complete because the researcher used the paper, whiteboard, board marker, phone camera.

These tools are good enough to get the data which it could be more subjective and learning process more effective and efficient. In teaching learning process was not running well because the students were less serious and enthusiasm in doing reading activities, some students still used their own strategies in reading comprehension where it could be seen from the result of research. There were 4 students were decline in second test.

Guessing strategy gave chance to the students to use target language for meaningful purposes; developed the students' reading comprehension and also improved their concentration in reading a text so that they could be more active and interested in learning reading comprehension. So, the researcher hoped Guessing strategy can be used in the classroom as one of the best strategies in teaching reading comprehension at grade XI MAS Darul Istiqomah Hutapadang Pijorkoling.

\section{CONCLUSION}

The hypothesis is accepted, in other word that guessing strategy improved students' reading comprehension at grade XI MAS Darul Istiqomah Hutapadang Pijorkoling. Based on the analyzing of research data, the mean score of students' reading comprehension in cycle 1 is $62.24(4 \%)$ and cycle 2 is 78.68 (79\%). The students' improvement is categorized as good. Then, the calculation result of $t_{o}=$ $13.77, t_{\text {table }}$ with $\mathrm{df}=18$, level of significance in $\mathrm{t}$ table $5 \%$ is 2.10 . It can be known that the result of $t_{o}$ is bigger than $t_{t}$, it is $13.77>2.10$. Based on the result, it means 
that there is a significant improvement between students' reading comprehension process result in the first cycle and second cycle. Some factors that influence students' reading comprehension by using guessing strategy are motivation, students who do disturbance, and students' who asking permission.

\section{REFERENCES}

A. Renandya, Richard, Language Teaching methodology, Cambridge: Cambridge University, 2000.

Bambang Setiadi, Teaching English as a foreign Language, Yogyakarta: Graha Ilmu, 2006.

Blaxter, Loraine, et.al, How To Research; Second Edition, Philadelphia: Open University Press, 1945.

Brown, H. Douglas, Language Assessment; Principles and Classroom Practices, USA: Longman, 2004.

Bull, Victoria, Oxford Learner's Pocket Dictionary, New York: Oxford University Press Fourth Edition, 2008.

Burns, Anne, Doing Action Research in English Language Teaching; A Guide for Practitioners, USA: Taylot and Francis, 2010.

C. Richards, Jack and Willy A. Renandya, Methodology in Language Teaching, United Kingdom: Cambridge University Press, 2002.

E. Mills, Geoffrey, Action Research a guide for The Teacher Researcher, New Jersey: Prentice Hall, 2000.

Gay, L.R and Peter Airasian, Educational Research; Competences for Analysis and Application, New Jersey: Prentice - Hall, Inc, 2000.

G. Paris, Acott and Ellen E. Hamilton, The development of Childrend's Reading Comprehension, New York: Taylor and Francis Group, 2009.

Hedge, Patricia, Teaching and Learning in the Classroom, Hongkong: Oxford Univercity Press, 2000.

Henry Guntur Tarigan, Membaca Sebagai Suatu Keterampilan Membaca, Bandung: Aksara, 1990.

Herbet H, Clark and Eve V Clark, Psychology and language: An Introduction tp Psycholingustics, (New York: Harcourt Brace Javanovich International Edition, 1977.

Hornby, A.S., Oxford Advanced Learned Dictionary $7^{\text {th }}$ Edition, New York: Oxford University Press, 2005.

Indah Permata Sari, "Improving Students' Reading Comprehension by Using PQ4R (Preview, Question, Read, Reflect, Recite and Review) Strategy at Grade VIII SMP Negeri Padangsidimpuan", (Unpublished Thesis), (Padangsidimpuan: IAIN Padangsidimpuan, 2014).

J. Harris, Albert, How to Increase Reading Ability; A Guide to Developmentaland Remedial Methods, Fifth Edition, New York: David Mckay Company, Inc, 1969.

J. Wallace, Michael, Action Reseach for Language Teacher, USA: Cambridge Univercity Press, 1998. 
List book of students' value at MAS Darul Istiqomah Hutapadang - Pijorkoling, private Document, MAS Darul Istiqomah Hutapadang - Pijorkoling: November $25^{\text {th }}, 2014$ at 10:30 am.

L. Oxford, Rebecca, Language Learning Strategies; What Every Teacher Should Know, New York: Newbury House Publishers, 1990.

Muhammad Taqi-ud-Din Al-Hilali and Muhammad Muhsin Khan, Translation of the Meanings of the Noble Qur'an in the English Language Madinah: King Fadh Complex for the Printing of Holy Qur'an, 1454.

Nasution, Nursalimah, "Improving Students' Reading Narrative Text Comprehension through Story Mapping Technique at Grade VIII MTsN 2 Padangsidimpuan", (Unpublished Thesis), (Padangsidimpuan: IAIN Padangsidimpuan, 2015).

Nunan, David, Practical English Language Teaching, New York: Mc. Grow Hill, 2003.

Otto, Wayne, How to Teach Reading, U.S.A: Addison-Wesley Publishing Company, 1979.

Riduan, Belajar Mudah Penelitian untuk Guru-Karyawan dan Penelitian Pemula Bandung: Alfabeta, 2005, p. 89.

Rochiati Wiratmaja, Metode Penelitian Tindak Kelas, Bandung: Rosda, 2005.

Roebl, K. M., Developing Reading Comprehension Skills in EFL University Level Students, (St. John's University: Taiwan, 2003).

Wainwright, Gordon, Speed Reading Better Recalling; Manfaatkan Teknik-teknik Teruji untuk Membaca Lebih Cepat dan Mengingat Secara Maksimal, Jakarta: PT. Gramedia Pustaka Utama, 2007. 